\title{
Harmin の生體家鬼子宮に及ぼす影響
}

\author{
柴田八 郎 \\ (岡山醫科大學藥理學敉室〔主任 奥島敉授]) \\ （昭和十八年五月十七日受付）
}

緒言

Harmin は Peganum harmalaの種子中に含まれるAlkaloid にして, Fischer ${ }^{1}$ )及びManske ${ }^{2}$ ) に據れば $\mathrm{C}_{13} \mathrm{H}_{12} \mathrm{~N}_{2} \mathrm{O}$ なる組成を有す. 本物質の燕理學的作用に關しては, Fury ${ }^{3}$ ), 瀨厅 ${ }^{4}$ ) 等 の家兔血厴, 耳款血管及び靑蛙剔出心藏に對する研究て據れば, 靑蛙に於ては一般に麻痺 作用を, 溫血動物に於ては興睢及び麻痺作用を呈すと述べをり. 余 ${ }^{5}$ ) も亦本物質の家鬼血. 㖉, 耳款血管及び蛙剔出心藏に對する作用を追試せしに本物質は剔出青蛙心藏に每常抑制

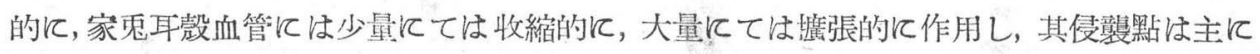
筋自已に存するもの〉如く, 又家槵血壓に對しては Harmin は一方血管運動中樞に麻痺的

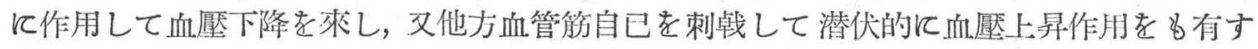

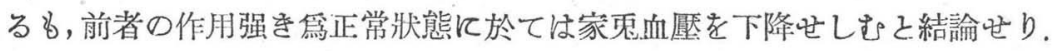

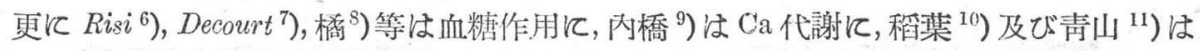
血液凝固に及ぼす Harmin の作用を檢索し, Harmin の過血糖亚にCa 減少及び血液凝固催 進の各作用は何れも中樞性にして，且交感种經性のものなりそ迅べたり．

次に本物質は平滑筋臟器就中摘出家鬼子宮に對しては瀨户によれば, 本物質の少量は 興奪作用を，大量は麻痺作用を呈し，Gunn ${ }^{12}$ ) は本物質は筋自己に作用し，興窟作用を呈す る己述べ Kreitmair ${ }^{13}$ ) は本物質は剔出子宮を 麻㿎せしむるも, 生體子宮に於ては興舊作用 を呈し，該作用は中樞性なりと棦せり，青山 ${ }^{19}$ ) は本物質の生體家鬼子宮に對する作用を檢 索し，子宮興奪作用を認め該作用は主として中樞性交感侪經刺趾に由來するものなりと結 論せり。

余は本報に於て Harmin の生體蒙兔子宮に及ぼす影響を窺ひ，前記諸家の認めたる本 物質の交感神經性中樞興舊作用を確認し, 次で該中樞性興舊が如何なる經路を經て子窝に 傳導せらるっやを檢し，以て本物質の作用機轉を一層鮮明ならしむると共に子窝に對する 交感神經性支配の關係を藥理學的觀點より明にせんとせり. 


\section{害驗方法及び璝驗材料}

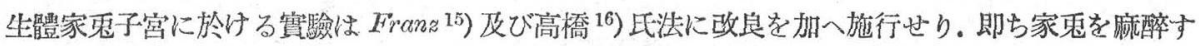
る事なく背位に固定し，下腹部に小四開定加へ，正中線に於て 耽骨縫際上皮慮に長さ 3 - $5 \mathrm{~cm}$ 切開を施

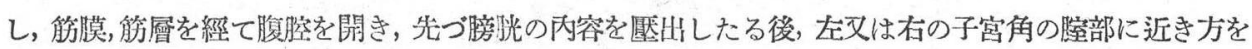

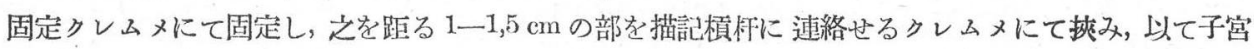

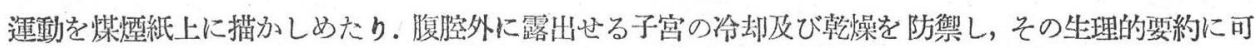
吏的變動を與へざらんが鹪, 余の作製せる恒溫恒濕裝置內にて行へり. 即ちガーゼにて被覆されたる天

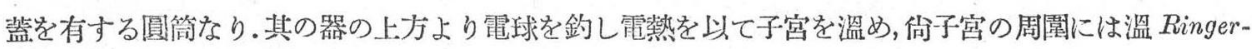
液にて濕したる綿を以て子宫を 被㻼し, 該臓器との間に 空陵を作りて子宮運動を阻害せざる如くし,

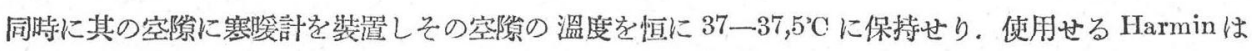

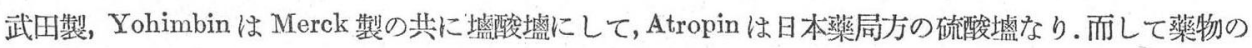
用量は常に體重 $1 \mathrm{~kg}$ に對する $\mathrm{mg}$ 量を以て記載せり。

\section{I. 正常家鬼子宮に於ける實驗}

\section{Harmin の單獨作用}

Harmin $1 \mathrm{mg}$ 老生體家鬼耳靜脈內に注入するに認むべき作用を認的ざるも，2 mg 亿至

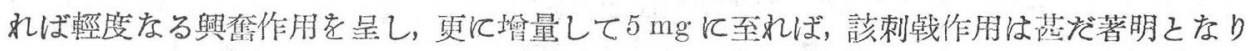
顯著なる緊張上昇妾呈す(第 1 圖參照). 更に大量 $10 \mathrm{mg}$ に至れば緊張上昇益及顯著にして,

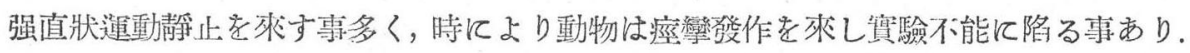

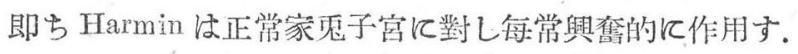

便宜上以後Harmin の量は $5 \mathrm{mg}$ (pro $\mathrm{kg}$ ) に一定し使用せり。

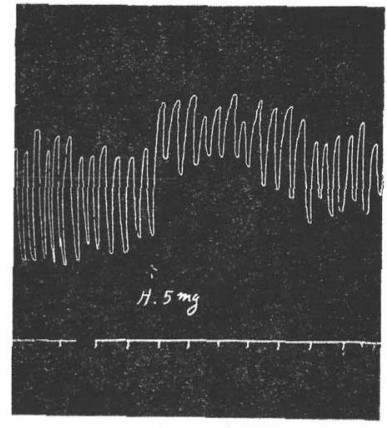

第 1 圖．正常家鬼子宮運動 Harmin 單獨作用.

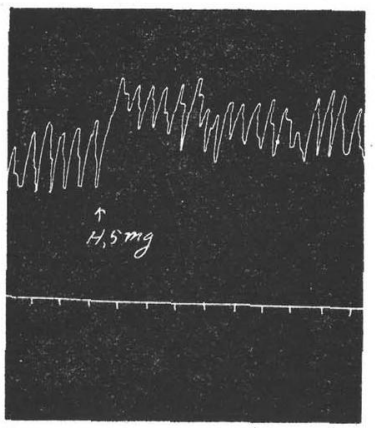

第 2 圖. 正常家鬼子宮 Atropin 作用後 Harmin の作用.

\section{Atropin との關係}

Cushny ${ }^{17}$ )によれば, Atropin は正常家蒐子営に對しては殆に゙影響を及ばさら゙るも, Pilo-

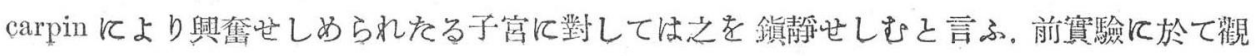


るが如き Harminの生體家亮子宫に對する興舊作用は果して副变感神經の刺㦸に因るや否

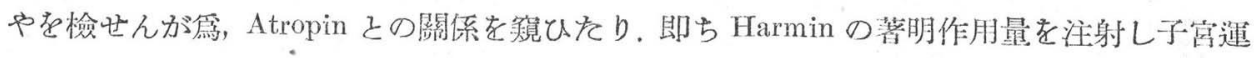

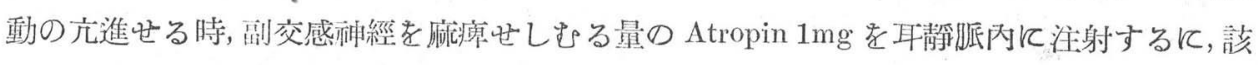
興奪作用は毫も抑制さる」事なし(第2 圖參照).

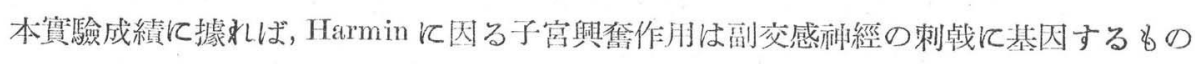
には非ざるが如し。

\section{Yohimbin との關係}

然らぱ Harmin による家鬼子宮興奪作用は交感神經の 刺㦸に因るに非ざるやを憸せん

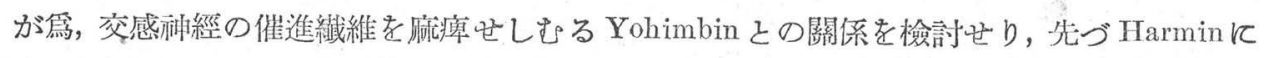
て子宮運動旺盛となりたる時Yohimbin $1 \mathrm{mg}$ を靜胍內に注射するに, 本物質に因る興奪作 用は完全に抑制さる (第3 圖參照). 又 Yohimbin 前處置後には本物質による子宮興舊作用 は毫当出現せず。

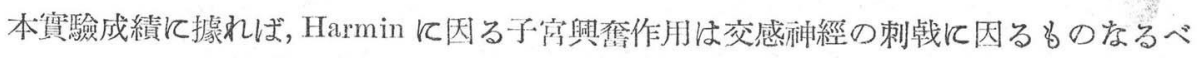
L.

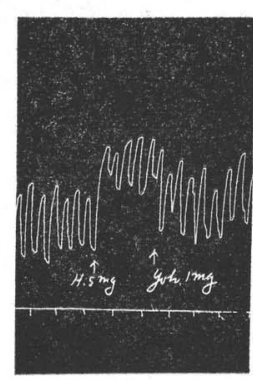

第3 圖. 正常家鬼 子宮 $Y$ ohimbin との關係.

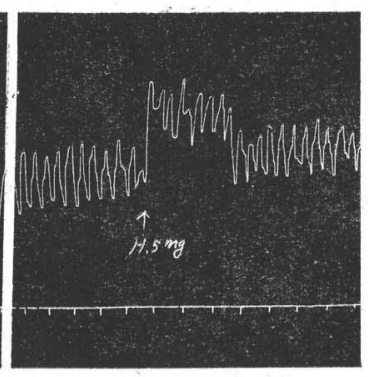

第 4 圖. Urethan 麻醉 家鬼子宮 Harmin の作用.

\section{II. 皮翼磨醉家鬼子宮に於ける實驗}

次に大腦皮質麻醉が Harmin の子宮興舊作用に如何なる影響を及ばすやを憸討せり. 先づUrethan 0,5一0,8 g を家兔の皮下に注射し, 約 $30^{\mathrm{m}}$ の後開腹し, 子宮運動を觀察するに, 正常家鬼に於ける子宮運動と殆ど同樣なる自働運動を續くるを觀る. 略及子宮運動の一定 せる時 Harmin を注射するに，顯著なる興舊作用を呈する事正常家鬼子宮に於にるが如し。

之に據つて觀れば，大腦皮質の麻醉は子宮の自働運動に格別の影響を及ばす事なく， 又 Harmin の子宮興舊作用は皮質より何等影響を被らざるが如し(第 4 圖).

\section{III. 腦幹栄醉家鬼子宮に於ける實驗}

腦幹揤醉藥Luminal ほ間腦に作用し其部に 屬する諸中樞を 麻痻せしさるは 幾多先賢 


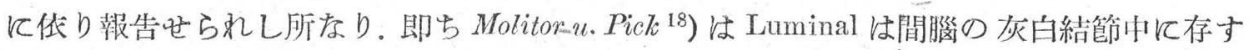

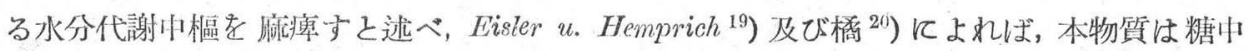
樞を, 內橋 ${ }^{21}$ ) は $\mathrm{Ca}$ 代謝中樞を, 青山 ${ }^{22}$ ) は血液凝固中慪を谳痺するものなる事を報告せ b.

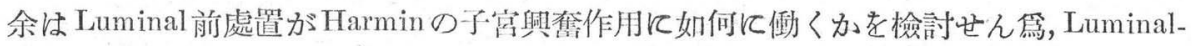
natrium $80 \mathrm{mg}$ 友下に注射し, 約 $30^{\mathrm{m}}$ の後開腹し, 子宮運動を描かしめ, 略从其の自働運 動の一定せし時 Harmin を作用せしむると, 何等興奪作用を認めず，之と據れば Harmin の 侵襲部位は主に間腦に存するには非ざるか。

然れども，一般に藥物の侵襲部位が間腦をりや否やを覚ふて際し，獨り Luminal 前處

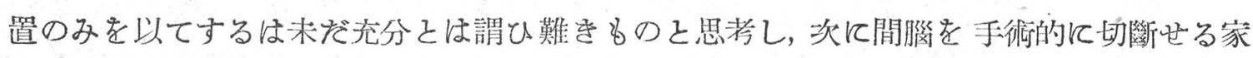
鬼に於て Harmin の作用を窺へり。

\section{IV. 間腦切斷家鬼子宮に於ける實驗}

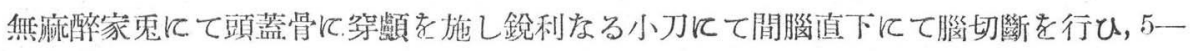
$6^{\mathrm{h}}$ 後 Harmin の前記量を静脈內に注射すると，何等興舊作用を呈せざる事 Luminal 前處置 の場合の如し。

以上の賽驗成績に㹉るに, 腦幹麻醉樂 Luminal 作用後及び間腦直下にて腦切斷後には

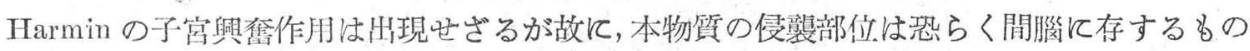
1 如L.

上述の諸實驗に據り Harminの家東生體子宮に對する興奮作用は交感神經刺战に因り，

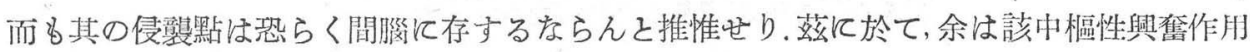
が如何なる經路により子宮に傳澾さる」かを詳細檢討せんとす。

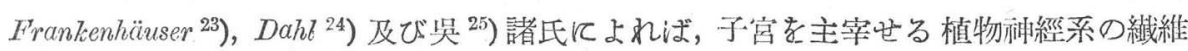

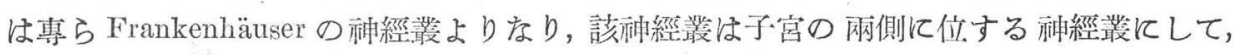

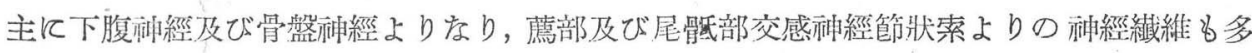

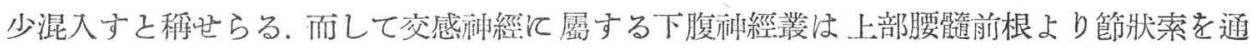

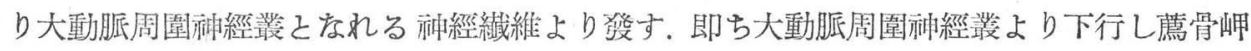
の高さに達する時は左右 2 本の神經丵に分れ省下行し子管體の高さにては下腹神經戬の㒳

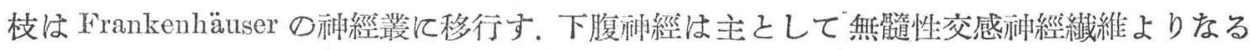

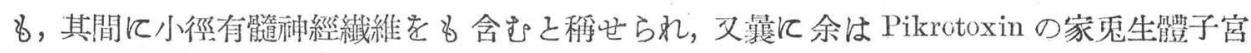

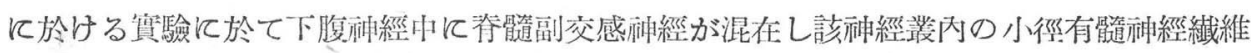

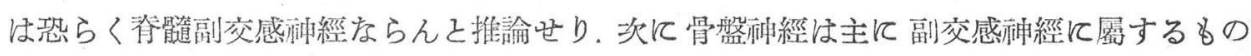
にして，薦䯕前根を通じ出でたる小徑有髓柛經繊維は當該腹部交感种經蓈狀索に入る事な 
く直接に腰薦神經丵中の䳸骨部を通過し，之より分離し 1 個又は 2 個の神經束となり骨盤 內に入り, Gaskel, Langley 氏等の說く所によれば節前纎維として 骨盤神經中に大るものな

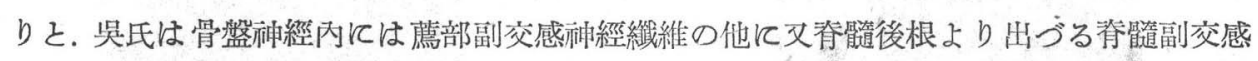

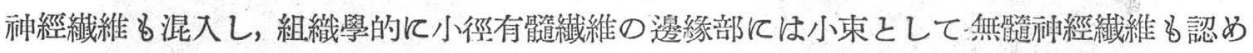
らるっと述べたり。次に萀咀部交感神經節より來る神經枝は節狀索神經節又は筋間神經枝 より出で Frankenhäuser 氏神經譵に入るものてして, 勿論主として無髓性交感神經節後纎維 よりなる。

余は以上の學說を基礎とし，種从の部にて神經切斷又は切除を行ひ，Harmin の作用に 及ぼす其の影響を憸し，以て Harmin に因る中楅性子宮作用の傳導經過を賽ふ己同時に，子 宮運動支配に閣する以上の學說を藥理學的に確認せんとせり。

\section{V. 胸髓切斷家鬼子宮に於ける賽驗}

前述せる如く, 子宮を支配せる交感神經は主として、上部腰帽遀より節狀索を經て大動脈

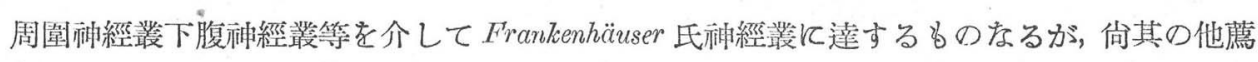

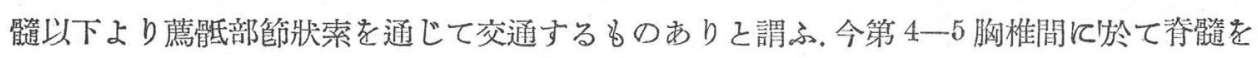

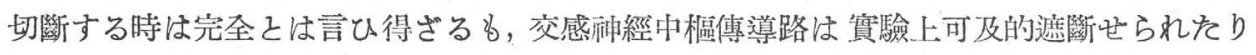
と稱し得べし.

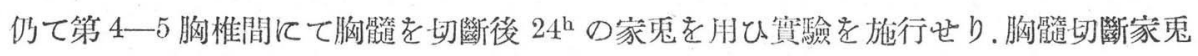
子宮の自働運動は、正常の場合飞比し多少振幅の減少を爽す。略及子宫運動一定せる時 Harmin を注射するに, 何等興奮作用を出現せず (第 5 圖參照)。

本實驗に據りHarmin により惹起せられたる中樞の交感种經性衝動は專ら䐧䯕を通り 下行するものなるべし.

\section{VI. 大動胍周園神經叢切除家鬼子宮に於ける贯驗}

前述の如く中樞よりの交感神經性衝動は大部分上腰䯠より大動脈周園神經箃を通り下 腹神經を經て子宮に傳達さる」もの店るが, 余は此の大動脈周圍神經叢を切斷し, Harmin の作用を察へり。

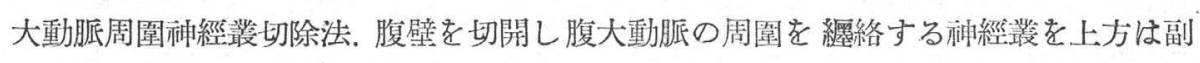
腎の邊りょり下部は腹部大動脈が左、右總腸骨動脈飞分岐する附近迄動脈を椇傷せざる如く

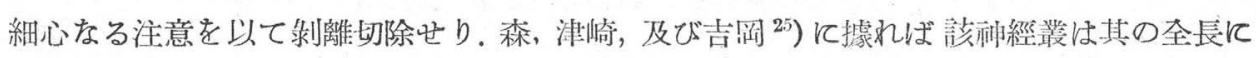
於て交感种經幹と微細なる神經によつて結合さる」ものにして, 副腎附近にては神經は微 細なるも尾側に至り次第に大となり腎動脈と下腸間膜動脈との間に於て最大となると言ふ.

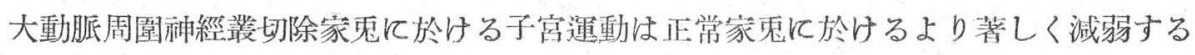




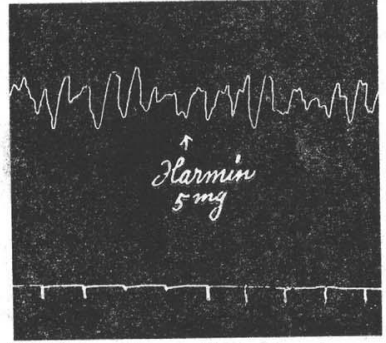

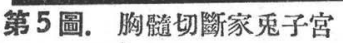
に於ける實驗。

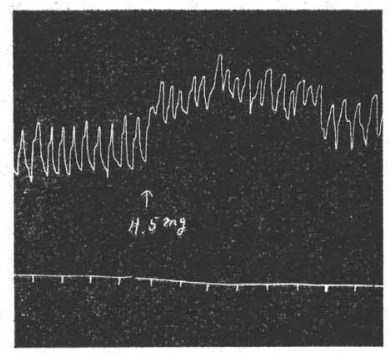

第 6 圖. 大動胙周園神經叢切除家鬼 子宮に於ける Harmin の作用.

も, 佮獨自の自働運動を呈す. 子宮運動の略及一定せる時 Harmin を作用せしむるに, 非手 術家鬼に於けるより微弱なるも矢張り同樣なる興奮作用を認屯 (第 6 圖參照).

然らば此の場合惹起せらるる興舊作用は中樞より如何なる經路により子宮に傳はりし ものなりや，前述子宮の神經支配により明かなるが如く本物質による中樞の交感种經性衝 動は此の場合に於ては主に鹰骮部交感神經節狀索よりの神經纎維を通じて子宮に傅はるも

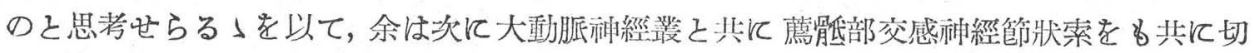
除せる家患子賞に於けるHarminの作用を窅へり。

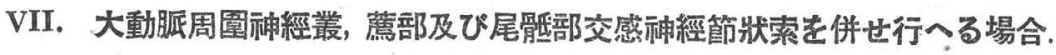

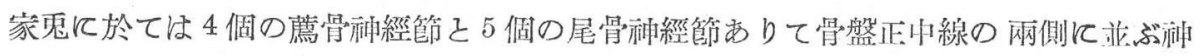
經節の連鎖なり. 該神經節切除は凡ての實驗操作中最も困雖索極めしものにして, 余は屍 體に於てその部位を確かわ, 充分熟練したる後開腹し, 手術による影響を可及的少くせんが

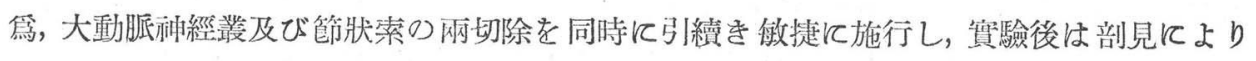
切除部位を㥀重に檢討せり。

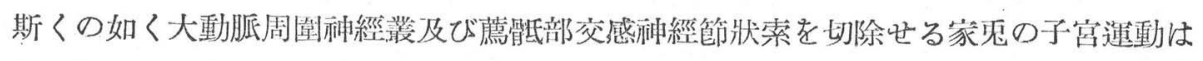
大動脈神經對のみの切除飞於ける以上に振幅の減少及び緊張の減弱を來す. 子営の自働運 動の一定せる時 Harmin を作用せしむるに, 多數例に於て極く輕微をる興奮作用を認 む(第 7 圖).

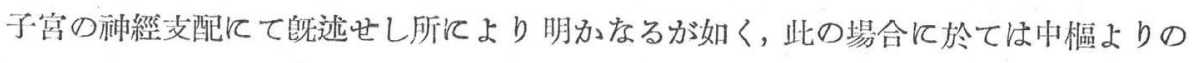

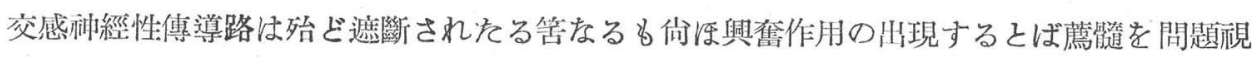
ぜざるべからず.

\section{VIII. 前 2 切除術に薦髓切斷を併せ施行せる場合}

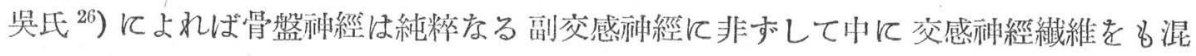

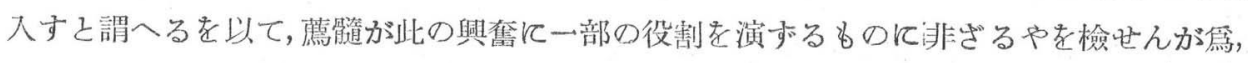

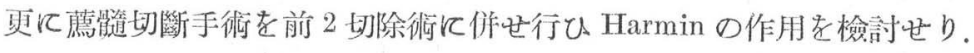




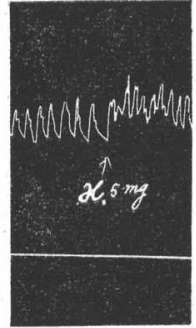

第 7 圖. 大動腿神經丵及び䳡骶部 交感神經節狀索切除に於りる Harmin の作用。

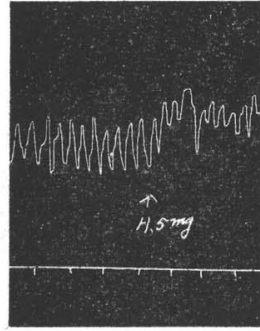

第 8 圖. 大動脈神經灌切除涉に萀艏切 斷家鬼子宮に於ける Harmin の 作用.

大動脈周圍神經丵及び萀骶部交感神經節狀索切除後萀髓を上端にて切斷し，子宮運動 の一定せる時 Harmin を注射せるに，何等興舊作用を認め和。

\section{IX. 大動眽周圍䢵經叢切除並に蔍髓切斷家鬼に於ける實驗}

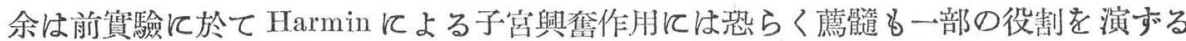

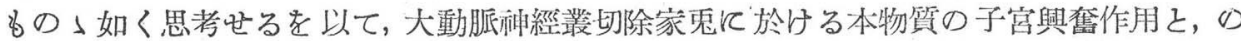

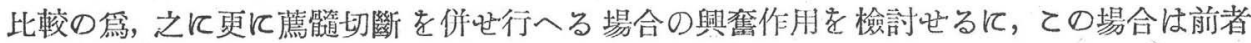
に比し子宮興奪作用の輕微なるを認めたり（第８圖參照）。

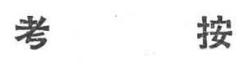

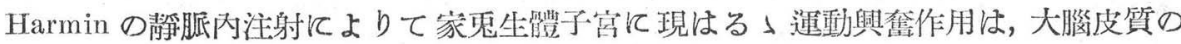
矿醉によりては影響なく、, Luminal 麻猝又は間腦切斷によりて消失するが故に中樞性にし て, 而もAtropin により少しも影響されボ, Yohimbin により全く抑制さるよが故に交感神 經性の興舊に基く事明なり。

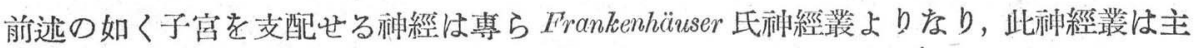

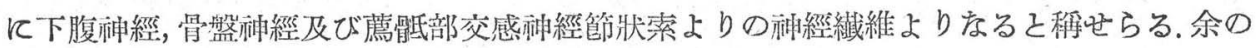
實驗に據れば大動脈周圍神經丵切除により下腹神經性傳導路を遮斷せし後にも Harmin の 子宮興舊作用は輕度ながら惹起せらる。從つて此の子宮興舊作用は主に萀骶部艾感神經節 狀索よりの神經によるものと思惟せらる」を以て, 更に（大動胍周圍神經叢切除に）該節 狀索切除を併せ施行せる家鬼子宮に於与る本物質の作用を䆖ふて, Harmin による中樞性交

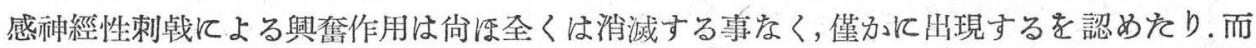
して此つ場合出現する輕微なる興奮作用は鹰髓切斷比より全く消失するとと〉又大動脈神

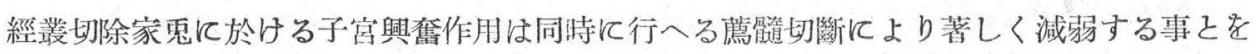

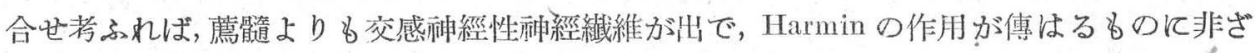
るかと考へらる。 
吳門下の田中 ${ }^{27}$ )は鹰骨第 1,2 种經前根刺钱の場合, 刺战當初又は刺㦸中陰蕉血管の流血. 量增加し, 中止後流血量の減少を來すを認め, 後者は前根を遠心性に通亦る交感神經も共に

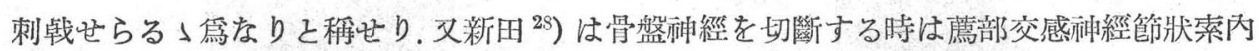
の神經細胞に變化を認め，是れ恐らく骨盤神經內の 無髓神經繊維の一部が此蓈狀蔡神經細 胞の節後繊維なるが雹なるべしと稱し，又腹部交感种經節狀索を全部剔出吃し犬に就き骨

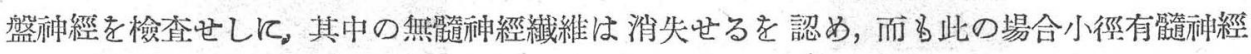
繊維は何等異常を認めざるを以て骨盤神經は純粹なる副交感神經繊維のみならす交感神經 纖維をも混入するものならんと推論せり.

以上生理學的及び組織學的研究に余の藥理學的實驗を併せ考察するに, Harmin により 起されたる中樞性交感神經性興奪は腹部大動脈种經叢より來をる交感神經の他に薦骶部交 感神經節狀索より出で 1 部骨盤种經にも混入する交感神經にも僡はるてと明にして, 倘痤

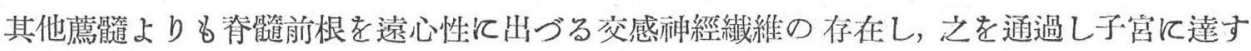

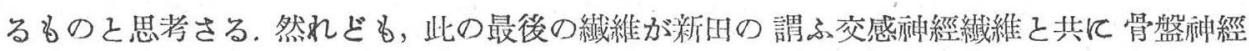
を通過する中否やは, 今後の研究に侯たざるべからず.

\section{結論}

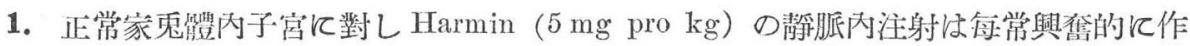
用し，著しき緊張上昇を來す。而して該子宮興奮作用は A tropin により何等影響さる」事な きもYohimbin にては完全に抑制さる。

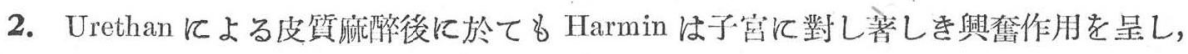
其の狀態正常家鬼に於りると大差を示さす。.

3. Luminalによる腦幹麻醉後又は閒腦直下にて腦切斷を施せる家鬼に於ては, 搳も本

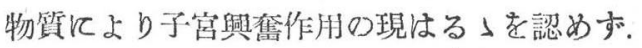

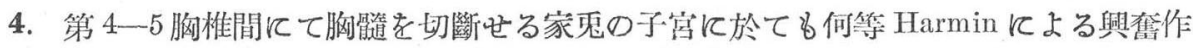
用を認さる能はす”。

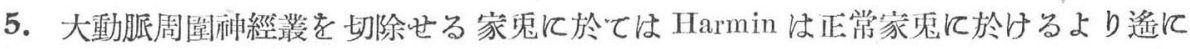
輕度なるも少原著明に興舊作用を呈す。

6. 大動脈神 經對切除己同時に薦骶部交感神經節 狀索切除を阙せ行へる場合には Honmin の作用は著しく減弱するも，倘僅かなる興㚛作用出現す。

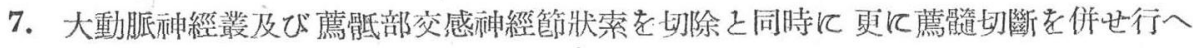
る家鬼に於ては Harmin は最早何等子宫興舊作用を呈せず。

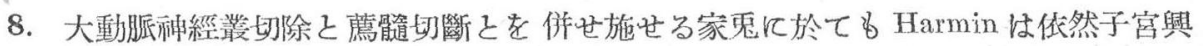


舊作用を呈するる前者のみ切除の場合に比すれば甚だ輕度なるを認む。

以上の䆩驗成績より Harmin の豙鬼生體子宮に 對する作用を考察すれは，本物質子宮 興舊作用は中楅性てして，其の侵襲點は閒腦に存し，その交感神經性催進中樞て作用する ๖のにして, 該中樞性衙動は總て胸髓を下行し, 其の大部分は胸腰部より脊䯕を出でて下 行し, 大動脈周圍神經坟を經て下腹种經に僡はり, 1 部は腰部より出で骨盤內交感神經節狀

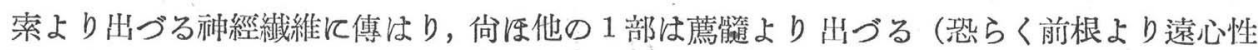
に）交感神經繊維を經て子宫に専達さる」ものならん。

\section{引用 畫 目}

1) Fïscher: Berichte d. Dtsch. Chem. Ges, 18, 400 (1885).

2) Manske: Journ. of Chem. Soc, 1 (1927).

3) Flury: Arch. f. exp. Path. u. Pharm., B. 64, 105 (1910).

4) 瀨戶：日本藥物學雜誌 9, 150 (昭和 4 年)；10, 15 (昭和 5 年).

5) 柴田：日本藥物學雜誌 38, 154 (昭和 18 年).

6) Risi: Ber. u̇. d. ges. Phys'iol. u. exp. Pharm., B. 61, 817 (1931).

7) Deeourt: C. r. Soc. Biol. Paris, Vol 104, P, 1209 (1930).

8) 滳: 日木藥物學襍誌 19,346 (昭和 10 年).

9) 內橋：日本藥物學雜誌 21, 77 (昭和 10 年).

10) 桼葉：日本藥物學雜誌 22, 14 (昭和 11 年).

11) 毒山: 岡山醫學會雜誌 51, (昭和 14 年).

12) Gunn: Arch. internat. de Pharm. et de Therap., 38, 507 (1930).

13) Kreitmair: Arch. f. exp. Path. u. Pharm., 147, 69 (1930).

14) 青山：岡山醫學會䊒誌 51, (昭和 14 年).

15) Frany: Zeitochr. f. Gef. u. Ggn., 53, 361 (1904).

16) 高橋：岡山醫學會雜誌 39, 506 (昭和 2 年)。

17) Oushny: Journ. of Physiol, 35, 1 (1907).

18) Molitor u. Pick: Arch. f. exp. Path u. Pharm., 107, 180 ebenda, u. 112, 113 (1926).

19) Eisler u. Hemprieh: Zeitschrift f. exp.Med., 83, 439 (1932).

20) 橘: 岡山醫學會椎誌 47, (昭和 10 年).

21) 内橋：同 47, (昭和 10 年).

22）青山：同 51，(昭和 14 年).

23) Frankenhäuser: Zit. n. Dahl 24, (1916).

24) Dahl: Zeitschr. f. Gef. u. Gyn. 78, (539).

25) 箖, 津, 崎, 吉岡：實驗用動物解剖學 (家鬼編)（昭和 10 年).

26 ) 吳：自律神經系，克誠堂書店 272,441 (昭和 10 年).

27) 田中： 東京醫學會雜誌 48, (昭和 9 年).

28) 新田：同 43, (昭和 4 年). 